\title{
TECHNICAL EFFICIENCY AND TOTAL FACTOR PRODUCTIVITY GROWTH IN THE HAZELNUT AGRICULTURAL SALES COOPERATIVES UNIONS IN TURKEY
}

\author{
Mehmet Candemir ${ }^{1}$, Mümin Özcan ${ }^{2}$, Mustafa Güneş², Ertuğrul Deliktaş ${ }^{3}$ \\ ${ }^{1}$ Department of Economics, Gediz University, Cankaya, Izmir, Turkey \\ ${ }^{2}$ Department of Industrial Engineering, Gediz University, Cankaya, Izmir, Turkey \\ ${ }^{3}$ Department of Economics, Ege University, Bornova-Izmir, Turkey \\ mehmet.candemir@gediz.edu.tr
}

\begin{abstract}
This study measures the production efficiencies and total factor productivity changes of Hazelnut Agricultural Sales Cooperatives Unions (HASCUs) in Turkey over the period 2004-2008. Turkey produces $\% 78.2$ hazelnut production of world and gives service to 233,820 farmers in the Black Sea Region of Turkey. To measure production efficiencies of these units, Data Envelopment Analysis (DEA) Approach and Malmquist Productivity Indexes are used. In the our efficiency analysis, the data of 50 HASCUs is considered but only the data of 37 cooperative units is found appropriate for the DEA. The findings of our study show that the average annual technical efficiency scores of HASCUs change between 0.841 and 0.938 . It has also been observed that there are average annual \%1.3 improvements in technical efficiency, 3\% regress in technical change, and \%1.7 decreases in the total factor productivity of the HASCUs over the period 2004-2008.
\end{abstract}

Key Words- Hazelnut agricultural sales cooperatives unions in Turkey, Data Envelopment Analysis, Malmquist Total Factor Productivity Indexes

\section{INTRODUCTION}

Hazelnut is one of the most important crops in the world and has its origins in the centre of Anatolia. Wild hazelnut species are found in Anatolia which has provided the source for today's cultivated varieties. Hazelnut is grown in the eastern and western regions of Turkey along the Black Sea Region. Hazelnut production in the Black Sea region extends from the Georgia's border to Istanbul. According to the statistics of Turkish Ministry of Agriculture, hazelnut production areas include 639.000 hectares. In Turkey, hazelnut farming regions are divided into four sub regions such as Akçakoca, Ordu, Giresun and Trabzon [1].

Turkey, as having the $78.22 \%$ of world production is the leader in the production and export of hazelnut. Italy, Spain, USA, Azerbaijan, and Georgia are other major hazelnut producers' countries. In Turkey, approximately three million people live on growing hazelnut; therefore it is easy to understand the strategic value of hazelnut production in the Black Sea Region. Hazelnut has also a different and special place in Turkish agriculture because it is mostly an export product. The $90 \%$ of hazelnut production is annually exported in Turkey. In total export, the share of agricultural 
product is $\% 12$ while the share of hazelnut is $\% 15$ in the agricultural product exported [2].

Turkish total hazelnut export including processed kernels realized as 228.401 tons and 1.407.871.663 \$ in 2008. Turkey has been exporting hazelnut to 32 countries. If we take account the processed types of hazelnut the number of countries increases to 100. The other majority of exported countries are European Union Countries. Almost 79 $\%$ of total exports are directed to EU. Germany is the leading importer of processed and unprocessed Turkish hazelnut with a share of approximately $27 \%$ of the total exported hazelnut, followed by Italy, France, Belgium, Switzerland, Russia and Netherlands [3].

The aim of this study is to examine the production performance of the HASCUs in terms of technical efficiency, change in technical efficiency, technological change and total factor productivity change. These criteria are commonly used by researcher in determining the production performance of the economic decision units. While the technical efficiency are defined as the ratio of the actual output to maximum output obtained by using the best production techniques or the willingness and ability of a cooperative unit to produce a maximum potential output with a given set of inputs and technology. In this sense, productivity and efficiency is not the same. Productivity is defined as the ratio of outputs to inputs. However, efficiency is a part of productivity. Total factor productivity change is divided into two main parts, namely technical efficiency change and technological change. The improvements in the technical efficiency and in technological change indices comprise the main element of reaching higher economic performance of decision making units and thus gaining higher competitive power. In this context, the technical efficiency improvement is accepted as an indicator of decision making units to adapt the global technology and therefore tells the "catch-up" part of the total factor productivity [4].

In the literature, there are various methods related to measuring the technical efficiency and total factor productivity change of decision making units. Among these the most commonly used two alternative methods are Stochastic Production Frontier Analysis (SFA) and Data Envelopment Analysis (DEA). Each approach has some advantageous and disadvantageous (see for more detail [5]). But, the main differences between the two approaches are while the SFA uses parametric methods, the DEA uses nonparametric (linear) programming methods. However, both approaches use the Malmquist Productivity Indexes to measure total factor productivity change.

In this study, we preferred to use the Data Envelopment Analysis to measure technical efficiency levels and in total factor productivity growth in HASCUs over the 2004-2008 periods. DEA has been used in many studies such as by Lowell [6], Fare at.al. [7], Ali and Seiford [8], Charnes et. al [9], Seiford [10], Coelli et. al. [11], Zaim and Taşkın [12], Karadag et. al. [13]. There is also a substantial body of literature measuring agricultural productivity growth using DEA, such as Çakmak and [14], Arnade [15], Rao and Coelli [11], Suhariyanto and Thirtle [16], Ruttan [24], Coelli and Rao [4], Nkamleu [17], Candemir and Deliktaş [18], Deliktaş at. al. [19], Candemir and Koyubenbe [20], Candemir and Deliktaş [21].

This paper has five sections include part. Section two describes the DEA and Malmquist Total Factor Productivity indexes employed in the study. Section three provides the data resources and variables that are used. Section four presents empirical findings of the study, and section five includes conclusion. 


\section{METHODOLOGY}

The empirical part of our study is based on Data Envelopment Analysis (DEA) developed by Charnes et al. [22]. DEA is a non-parametric approach and it doesn't require any functional for a given data. This method uses input and output data of decision making units to construct a piece-wise linear surface or the best-practice frontier for a given data. The best practice frontier that represent full efficiency level of the units is constructed by the solution of a sequence of linear programming problems for each units or enterprise.

DEA can be either used in output oriented form or input oriented form depending on the purpose of researcher. If our aim is to evaluate the input usage of firm by holding output produced is constant we should use the input oriented approach. Because the input oriented DEA method seeks the maximum possible proportional decrease in input usage with a given output levels. But if our aim is to know whether maximum possible output is produced by the decision making units with a given set of inputs, we should use output oriented approach. The output oriented approach seeks the maximum possible proportional increase in output wit a given set of inputs. However, under the constant returns to scale technology, these two approaches give the same results in terms of technical efficiency index, but under the variable returns to scale technology technical efficiency index may differ [4].

In this study, we used the output-oriented DEA model under the constant returns to scale, because we assumed that the HASCUs should maximize their outputs with a given set of inputs. Following Coelli and Rao [4] the output-oriented DEA model for N enterprises in a particular time period can be defined as follows.

$$
\begin{aligned}
& \max _{\phi, \lambda} \phi, \\
& s t-\phi y_{i t}+Y \lambda \geq 0, \\
& x_{i t}-X \lambda \geq 0, \\
& \lambda \geq 0,
\end{aligned}
$$

where $y_{i}$ is a $M x 1$ vector of output quantities for the $\mathrm{i}$-th enterprise; $\mathrm{X}_{1}$ is a Kx1 vector of input quantities for the $\mathrm{i}$-th enterprise; $\mathrm{Y}$ is a NxM matrix of output quantities for all $\mathrm{N}$ enterprises; $\mathrm{X}$ is a NxK matrix of input quantities for all $\mathrm{N}$ enterprises; $\lambda$ is a $\mathrm{Nxl}$ vector of weights, which provides information on the peers of the inefficient $i$-th enterprise, and $\varnothing$ is a scalar that shows efficiency levels of the enterprises.

The scalar will take value between $1 \leq \phi<\infty$, and $\phi-1$ indicates the proportional increase in outputs that could be produced by the i-th enterprise. Then, $1 / \varnothing$ defines technical efficiency index, which varies between zero and one, with a value of one indicating any point on the frontier or full efficiency for the i-th enterprise and with a value of smaller than one or below the best-practice frontier indicating in efficiency.

Data envelopment analysis uses Malmquist productivity indexes based on input oriented or output oriented distance functions. In this study, we used the output oriented distance function to determine the best-practice production frontier, because our aim is to measure the maximal increase in agricultural production, with a given set of inputs of the HASCUs. 
By following Coelli et al. [11] and Fare et.al.[7] we define production technology $\mathrm{S}^{\mathrm{t}}$ for each time period $t=l, \ldots, T$, which represents the outputs, $\mathrm{y},=\{$ $\left.\mathrm{y}_{\mathrm{x}}, \ldots \ldots, \mathrm{y}_{\mathrm{M}}\right)$, which can be produced using the inputs $\mathrm{x}_{\mathrm{t}}=\left\{\mathrm{x}_{\mathrm{i}}, \ldots, \mathrm{x}_{\mathrm{K}}\right)$, as:

$$
S^{t}=\left\{\left(x^{t}, y^{t}\right): x^{t} . \text { can..produce.. } y^{t}\right\}
$$

where $\mathrm{x}$ is a non-negative input vector $\mathrm{x}=\left(\mathrm{x}_{1}, \mathrm{x}_{2}, \ldots . \mathrm{x}_{\mathrm{n}}\right)$ and $\mathrm{y}$ is a non-negative output vector $\mathrm{y}=\left(\mathrm{y}_{1}, \mathrm{y}_{2} \ldots \ldots \ldots \mathrm{y}_{\mathrm{m}}\right)$. Malmquist productivity change index between period $\mathrm{t}$ and $\mathrm{t}+1$ is defined as follows [7].

$$
M_{0}\left(y^{t}, x^{t}, y^{t+1}, x^{t+1}\right)=\left[\left(\frac{D_{0}^{t}\left(y^{t+1}, x^{t+1}\right)}{D_{0}^{t}\left(y^{t}, x^{t}\right)}\right) x\left(\frac{D_{1}^{t+1}\left(y^{t+1}, x^{t+1}\right)}{D_{1}^{t+1}\left(y^{t}, x^{t}\right)}\right]^{\frac{1}{2}}\right.
$$

where $D_{1}^{t+1}\left(x_{t}, y_{t}\right)$ denotes the distance from the period $\mathrm{t}$ observation to the period $\mathrm{t}+1$ technology. Malmquist total factor productivity index has two components, namely technical efficiency and technical changes. The decomposition of the TFPC index as follows:

$$
\begin{aligned}
& \text { Efficiency Change (EC) }=\frac{D_{0}^{1+1}\left(x_{1+1}, y_{1+1}\right)}{D_{0}^{1}\left(x_{1}, y_{1}\right)} \\
& \text { Technical Change (TQ) }=\left[\left(\frac{D_{0}^{t}\left(y^{t+1}, x^{t+1}\right)}{D_{1}^{t+1}\left(y^{t+1}, x^{t+1}\right)}\right) x\left(\frac{D_{0}^{t}\left(y^{t}, x^{t}\right)}{D_{1}^{t+1}\left(y^{t}, x^{t}\right)}\right)\right]^{\frac{1}{2}}
\end{aligned}
$$

or $\quad \mathrm{M}_{\mathrm{o}}^{\mathrm{t}, \mathrm{t}+1}=$ Efficiency Change $\mathrm{x}$ Technical Change

The efficiency change measures the degree of catching up to the best- practice frontier for each observation between period $t$ and period $t+1$ (Coelli et al. [11] and Nkamleu [17]). On the other hand, the technical change index measures the shift in the frontier of technology or innovation between two adjacent time periods. However, it does not tell us which unit actually caused the frontier to shift. In order to find out innovator enterprises, we can look at the component distance functions in the technical change index. This index tells us what happened to the production frontier at the input level and mix of each unit. Then, that unit has contributed to a shift production frontier between period $t$ and $t+1$, Fare et al. [7]. That is,

$$
\begin{aligned}
& \mathrm{TC}^{\mathrm{k}}>1 \\
& \mathrm{D}^{\mathrm{t}}{ }_{0}\left(\mathrm{x}^{\mathrm{k}, \mathrm{t}+1}, \mathrm{y}^{\mathrm{k}, \mathrm{t}+1}\right)>1 \text { and } \\
& \mathrm{D}^{\mathrm{k}, \mathrm{t}+1}{ }_{0}\left(\mathrm{x}^{\mathrm{k}, \mathrm{t}+1}, \mathrm{y}^{\mathrm{k}, \mathrm{t}+1}\right)=1
\end{aligned}
$$

where $\mathrm{k}$ denotes each decision- making unit. 
The Malmquist total factor productivity change indexes can be calculated using DEA-like linear programs. For the $i$-th enterprise, the DEA calculates four distance functions to measure the TFP change between two periods (for more detail see, Fare et al [7]).

The data used in this study is obtained from 2004-2008 accounting records of 37 Hazelnut Agricultural Sales Cooperatives Union. The inputs used in DEA are sales costs, operating expenditures, value of plant and equipment of each enterprise. The output includes the total annual gross sale revenues, other incomes and value of net stocks at the end of year. All monetary values are measured in constant prices by taking 2003 as the base year.

\section{EMPIRICAL RESULTS}

The Data Envelopment Analysis (DEA) is applied to a sample of 37 Hazelnut Agricultural Sales Cooperatives Union over the period 2004-2008. Then, technical efficiency and total factor productivity growth indices are obtained using the computer program DEAP 2.1 written by Coelli [23].

\subsection{Technical Efficiency}

Both technical efficiency levels of 37 cooperatives and annual average technical efficiency level of four regions including different number of cooperatives are given in the Table 1 over the 2004-2008 periods. Then, Table 1 can be interpreted in terms of individual cooperatives but we preferred to interpret annual averages of each region. From this viewpoint, the Akçakoca region (Western Black Sea Region) has the highest annual average technical efficiency level while the Giresun Region (eastern Black Sea Region) has the lowest technical efficiency level among the regions.

The regional annual technical efficiency levels of HASCUs are also shown by Figure 1. It is seen that, in the figure 1, the annual technical efficiency level of Giresun region declines sharply until 2005, and then after this year it reaches it's the highest point (full efficiency) in 2008. That is, Giresun region has successful in catching up the other regions. It also seems that Ordu and Trabzon regions experienced high performance from the end of 2005 and overtook the Akçakoca region. All regions almost have same technical efficiency scores in 2008 that is they converged to each other. However, no region has full efficiency, on average.

\subsection{Total Factor Productivity Growth}

The total factor productivity growth index is decomposed into technical efficiency change and technical change indices. If technical efficiency change index is greater than one, it means that there is an improvement in efficiency or catching-up effect the best practice frontier. On the other hand, if it is less than one it shows a deterioration in production performance of the decision making unit. The technical efficiency change is also decomposed into pure efficiency and change and scale efficiency changes. The scale efficiency change index being greater one indicates the 
success of cooperative to produce in optimal scale, while pure efficiency change index greater one indicates that there is a learning process in the decision making unit [17].

Table 1. Technical Efficiency Levels of the HASCUs (2004-2008)

\begin{tabular}{|c|c|c|c|c|c|c|c|}
\hline \multirow{2}{*}{$\begin{array}{l}\text { Region of } \\
\text { hazelnut }\end{array}$} & \multirow{2}{*}{$\begin{array}{l}\text { Name } \\
\text { of Cooperative }\end{array}$} & \multicolumn{5}{|c|}{ Year } & \multirow[b]{2}{*}{ mean } \\
\hline & & 2004 & 2005 & 2006 & 2007 & 2008 & \\
\hline \multirow[t]{12}{*}{ Akçakoca } & AKÇAKOCA & 0.858 & 1.000 & 1.000 & 1.000 & 1.000 & 0.972 \\
\hline & ALAPLI & 0.843 & 0.898 & 0.825 & 0.814 & 0.929 & 0.862 \\
\hline & BARTIN & 0.781 & 1.000 & 1.000 & 0.812 & 0.933 & 0.905 \\
\hline & CUMAYERI & 1.000 & 0.792 & 0.919 & 0.779 & 0.928 & 0.884 \\
\hline & ÇİLIMMLI & 1.000 & 0.984 & 1.000 & 0.986 & 1.000 & 0.994 \\
\hline & DÜZCE & 0.848 & 0.868 & 0.824 & 0.790 & 0.937 & 0.853 \\
\hline & GÖLYAKA & 0.830 & 0.976 & 0.920 & 0.966 & 0.928 & 0.924 \\
\hline & GÜMÜŞOVA & 0.832 & 0.927 & 0.894 & 0.861 & 0.929 & 0.889 \\
\hline & HENDEK & 0.954 & 0.995 & 0.982 & 0.842 & 0.930 & 0.941 \\
\hline & KARASU & 1.000 & 1.000 & 1.000 & 0.825 & 0.929 & 0.951 \\
\hline & KOCAALI & 0.908 & 0.770 & 0.981 & 0.791 & 0.929 & 0.876 \\
\hline & UĞURLU & 0.833 & 0.938 & 0.811 & 0.827 & 0.913 & 0.864 \\
\hline \multirow[t]{9}{*}{ Ordu } & ÇAMLAŞ & 0.969 & 0.852 & 0.907 & 1.000 & 0.858 & 0.917 \\
\hline & ÇARŞAMBA & 1.000 & 1.000 & 1.000 & 1.000 & 0.965 & 0.993 \\
\hline & FATSA & 0.860 & 0.823 & 0.952 & 0.818 & 0.930 & 0.877 \\
\hline & GÖLKÖY & 0.830 & 0.703 & 0.984 & 0.830 & 0.946 & 0.859 \\
\hline & KUMRU & 0.844 & 0.764 & 0.992 & 0.813 & 0.931 & 0.869 \\
\hline & ORDU & 0.824 & 0.826 & 0.987 & 0.817 & 0.927 & 0.876 \\
\hline & PERŞEMBE & 0.832 & 0.816 & 0.968 & 0.819 & 0.972 & 0.881 \\
\hline & TERME & 0.832 & 0.834 & 1.000 & 0.812 & 0.982 & 0.892 \\
\hline & ÜNYE & 0.880 & 0.793 & 0.947 & 1.000 & 0.932 & 0.910 \\
\hline \multirow[t]{7}{*}{ Giresun } & BEŞİKDÜZÜ & 1.000 & 0.644 & 0.733 & 1.000 & 0.932 & 0.862 \\
\hline & BULANCAK & 0.882 & 0.717 & 0.843 & 0.810 & 0.936 & 0.838 \\
\hline & EYNESİL & 0.843 & 0.776 & 0.952 & 1.000 & 1.000 & 0.914 \\
\hline & GİRESUN & 0.856 & 0.696 & 0.899 & 0.798 & 0.929 & 0.836 \\
\hline & KEŞAP & 1.000 & 0.688 & 0.808 & 0.793 & 0.930 & 0.844 \\
\hline & TİREBOLU & 1.000 & 0.749 & 0.537 & 0.997 & 0.930 & 0.843 \\
\hline & VAKFIKEBİR & 0.998 & 0.684 & 0.777 & 1.000 & 0.934 & 0.879 \\
\hline \multirow[t]{9}{*}{ Trabzon } & AKÇAABAT & 1.000 & 0.942 & 1.000 & 0.828 & 0.930 & 0.940 \\
\hline & ARAKLI & 0.907 & 0.844 & 0.970 & 0.831 & 0.927 & 0.896 \\
\hline & ARSIN & 0.857 & 0.827 & 0.999 & 0.813 & 0.928 & 0.885 \\
\hline & BORÇKA & 0.979 & 0.884 & 0.626 & 1.000 & 1.000 & 0.898 \\
\hline & DERECİK & 0.839 & 0.855 & 1.000 & 0.828 & 0.928 & 0.890 \\
\hline & MAÇKA & 0.847 & 0.750 & 1.000 & 0.884 & 0.977 & 0.892 \\
\hline & SÜRMENE & 0.667 & 0.831 & 0.966 & 0.811 & 0.927 & 0.840 \\
\hline & TRABZON & 0.996 & 0.827 & 0.913 & 1.000 & 0.928 & 0.933 \\
\hline & YOMRA & 0.879 & 0.863 & 0.986 & 0.818 & 0.928 & 0.895 \\
\hline \multicolumn{2}{|c|}{ General Mean } & 0.895 & 0.841 & 0.916 & 0.871 & 0.938 & 0.892 \\
\hline
\end{tabular}



Agricultural Sales Cooperatives Unions in Turkey

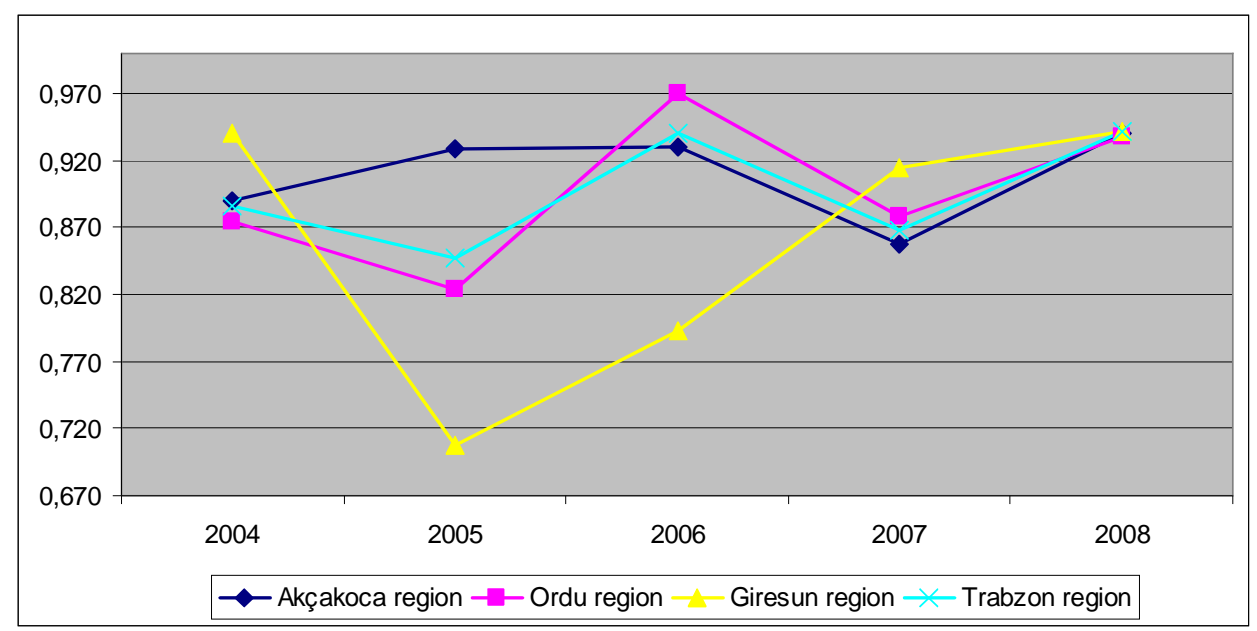

Figure 1. Regional Annual Technical Efficiency Levels of the HASCUs

The annual average indexes of total factor productivity growth components for the HASCUs are reported Table 2. The technical efficiency change index of 37 cooperatives shows that the level of efficiency has increased $1.3 \%$ over the whole period. The source of this growth depends on improvement in scale efficiency. The annual average technological change index for 37 cooperative units is measured as 0.970 for whole period. In other words, there is a technological regress which is $3 \%$, on average. Technical change index being smaller than one shows technical regress or downward movement of the best practice frontier while its being greater than one means the upward movement of production frontier or technical progress. When the HASCUs are considered separately, the results show that Akçakoca, Bartın, Çamlaş, Gölköy, Kumru, Ordu, Ünye, Araklı cooperative units experience technological progress. These cooperatives also shift upward the best practice frontier or production function by the method described by Fare et. al. [7].

$$
T C>1, D_{0}^{t}\left(x_{t+1}, y_{t+1}\right)>1, D_{0}^{t+1}\left(x_{t+1}, y_{t+1}\right)=1
$$

Total factor productivity change (TFPC) is simply the multiplication of efficiency and technological change indices. These two changes constitute the total factor productivity growth index. The last column of Table 2 provides the average annual growth for the Hazelnut Agricultural Sales Cooperatives Union in Turkey over the study period. As can be seen from the Table 2, the total factor productivity has decreased by 1.7 percent, on average, due to the annual average technical regress for 37 cooperatives. In the other words, the technical change has been the main constraint of achievement of high levels of total factor productivity growth over the study period, because 1.3 percent improvement in technical efficiency was outweighed by 1.7 percent technical regress. On the other hand, the Ordu region has performed well in total factor productivity growth. On average, the total factor productivity of this region has increased by 0.4 percent due to improvement in technical efficiency and technical progress over the 2004-2008 periods. The annual TFPC components indexes of the HASCUs are also plotted in Figure 2. The Figure illustrates regional averages of technical efficiency change, technical change and total factor productivity change over 
time. Technical change is sometimes bigger than one in the Figure, but mostly lies under one. Technical efficiency change lies mostly over one. Then, as a result of these two indices the TFPC has increased until 2006 then it started to decrease through the period of 2006-2008.

Table 2. Average Total Factor Productivity Growth Components for the HASCUs (2004- 2008)

\begin{tabular}{|c|c|c|c|c|c|c|}
\hline $\begin{array}{l}\text { Region of } \\
\text { Hazelnut }\end{array}$ & $\begin{array}{l}\text { Name of } \\
\text { Cooperative }\end{array}$ & $\begin{array}{l}\text { Technical } \\
\text { efficiency } \\
\text { Change }\end{array}$ & $\begin{array}{l}\text { Technical } \\
\text { change }\end{array}$ & $\begin{array}{l}\text { Pure } \\
\text { efficiency } \\
\text { change }\end{array}$ & $\begin{array}{l}\text { Scale } \\
\text { efficiency } \\
\text { change }\end{array}$ & $\begin{array}{l}\text { Total factor } \\
\text { productivity } \\
\text { change }\end{array}$ \\
\hline \multirow[t]{13}{*}{ Akçakoca } & AKÇAKOCA & 1.039 & 1.092 & 1.000 & 1.039 & 1.135 \\
\hline & ALAPLI & 1.025 & 0.985 & 1.009 & 1.016 & 1.009 \\
\hline & BARTIN & 1.045 & 0.992 & 1.037 & 1.008 & 1.037 \\
\hline & CUMAYERİ & 0.982 & 0.900 & 0.982 & 1.000 & 0.884 \\
\hline & ÇİLİMLİ & 1.000 & 1.009 & 1.000 & 1.000 & 1.009 \\
\hline & DÜZCE & 1.025 & 0.953 & 0.999 & 1.026 & 0.977 \\
\hline & GÖLYAKA & 1.028 & 0.968 & 1.014 & 1.014 & 0.996 \\
\hline & GÜMÜŞOVA & 1.028 & 0.960 & 1.006 & 1.022 & 0.987 \\
\hline & HENDEK & 0.994 & 0.990 & 1.003 & 0.991 & 0.983 \\
\hline & KARASU & 0.982 & 0.958 & 0.988 & 0.994 & 0.941 \\
\hline & KOCAALI & 1.006 & 0.922 & 1.007 & 0.999 & 0.928 \\
\hline & UĞURLU & 1.028 & 0.956 & 0.998 & 1.030 & 0.982 \\
\hline & Mean & 1.015 & 0.974 & 1.004 & 1.002 & 0.989 \\
\hline \multirow[t]{10}{*}{ Ordu } & ÇAMLAŞ & 0.970 & 1.047 & 0.970 & 1.000 & 1.016 \\
\hline & ÇARŞAMBA & 0.991 & 0.982 & 0.997 & 0.994 & 0.973 \\
\hline & FATSA & 1.020 & 0.940 & 0.995 & 1.024 & 0.959 \\
\hline & GÖLKÖY & 1.033 & 1.015 & 1.023 & 1.010 & 1.049 \\
\hline & KUMRU & 1.025 & 1.014 & 1.003 & 1.021 & 1.039 \\
\hline & ORDU & 1.030 & 1.008 & 1.002 & 1.028 & 1.038 \\
\hline & PERȘEMBE & 1.028 & 0.948 & 1.011 & 1.017 & 0.974 \\
\hline & TERME & 1.028 & 0.935 & 1.002 & 1.026 & 0.961 \\
\hline & ÜNYE & 1.014 & 1.013 & 0.991 & 1.024 & 1.028 \\
\hline & Mean & 1.016 & 0.989 & 0.999 & 1.015 & 1.004 \\
\hline \multirow[t]{8}{*}{ Giresun } & BEȘIKKDÜZÜ & 0.983 & 0.930 & 0.983 & 0.999 & 0.914 \\
\hline & BULANCAK & 1.015 & 0.956 & 0.994 & 1.020 & 0.970 \\
\hline & EYNESİL & 1.043 & 0.994 & 1.027 & 1.016 & 1.037 \\
\hline & GİRESUN & 1.021 & 0.967 & 1.004 & 1.016 & 0.987 \\
\hline & KESAP & 0.982 & 0.984 & 0.982 & 1.000 & 0.967 \\
\hline & TİREBOLU & 0.982 & 0.970 & 0.988 & 0.994 & 0.953 \\
\hline & VAKFIKEBİR & 0.983 & 0.906 & 0.984 & 1.000 & 0.891 \\
\hline & Mean & 0.862 & 0.958 & 0.995 & 1.006 & 0.960 \\
\hline \multirow[t]{10}{*}{ Trabzon } & AKÇAABAT & 0.982 & 0.882 & 0.982 & 1.000 & 0.866 \\
\hline & ARAKLI & 1.006 & 1.001 & 1.005 & 1.000 & 1.007 \\
\hline & ARSIN & 1.020 & 0.920 & 0.996 & 1.024 & 0.938 \\
\hline & BORÇKA & 1.005 & 0.989 & 1.005 & 1.000 & 0.994 \\
\hline & DERECIKK & 1.026 & 0.979 & 0.997 & 1.028 & 1.004 \\
\hline & MAÇKA & 1.036 & 0.988 & 1.019 & 1.017 & 1.024 \\
\hline & SÜRMENE & 1.086 & 0.921 & 0.991 & 1.096 & 1.000 \\
\hline & TRABZON & 0.982 & 0.971 & 0.998 & 0.985 & 0.954 \\
\hline & YOMRA & 1.014 & 0.984 & 1.001 & 1.013 & 0.998 \\
\hline & Mean & 1.018 & 0.960 & 0.999 & 1.018 & 0.976 \\
\hline \multicolumn{2}{|c|}{ General Mean } & 1.013 & 0.970 & 1.000 & 1.013 & 0.983 \\
\hline
\end{tabular}



Agricultural Sales Cooperatives Unions in Turkey

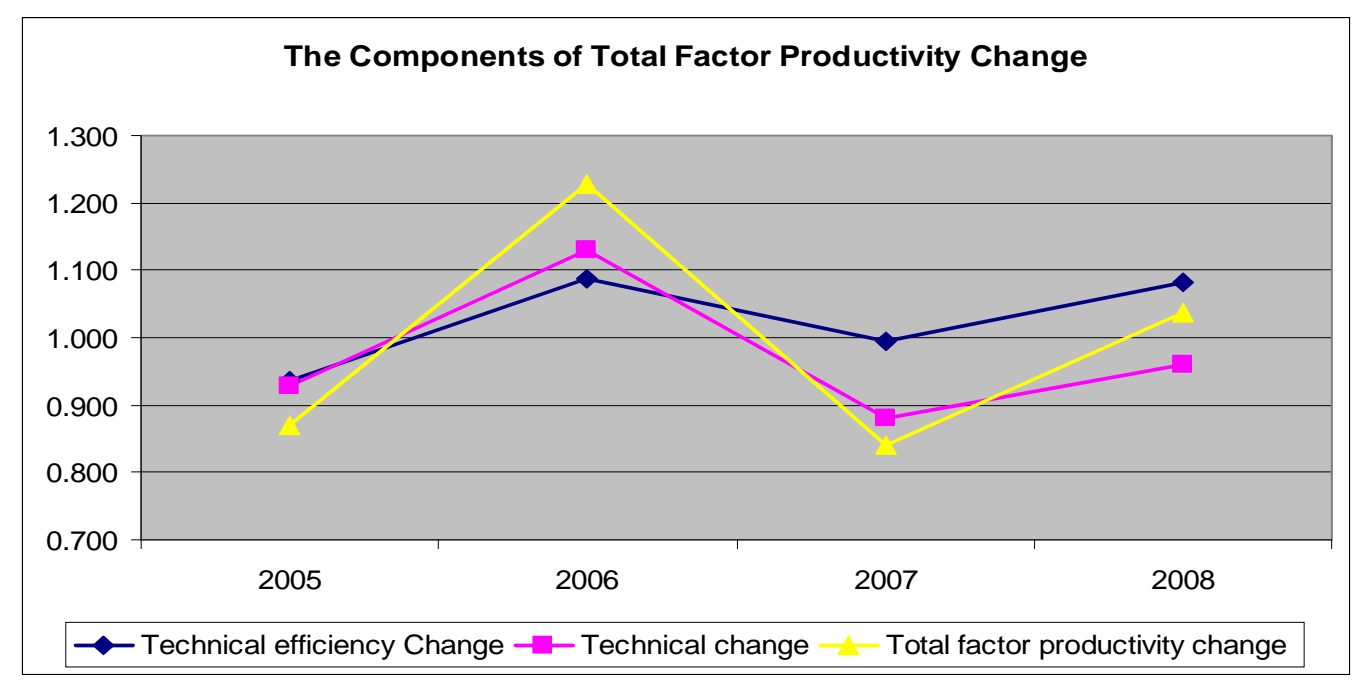

Figure 2. The indices of technical efficiency change, technical change and total factor productivity change

\section{CONCLUDING REMARKS}

In this study, the relative performance of 37 Hazelnut Agricultural Sales Cooperatives Unions (HASCUs) located in the Black Sea region of Turkey was measured over the period 2004-2008. The relative performance measurements based on technical efficiency level, technical efficiency change, technological change and total factor productivity change indices of the HASCUs were calculated by using Data Envelopment Analysis.

The results of the study indicate that the average annual technical efficiency index for the HASCUs is less than one indicating that the cooperatives generally could not produce maximum output with a given set of inputs for 2004-2008 periods. However, the most cooperatives that have efficiency change indices bigger than one were found successful in catching-up the best production frontier. The obtained negative annual average technical progress for the cooperatives indicates that technical change has been the main constraint of achievement of high levels of total factor productivity growth for the HASCUs in the study period.

On the other hand, when we examine the regions separately, the results show that the regions including various numbers of cooperatives have different production performance. It was found that the Akçakoca region (Western Black Sea Region), on average, has the highest technical efficiency level while Giresun region (eastern Black Sea Region) has the lowest technical efficiency index level among the regions. Trabzon, Ordu, Akçakoca regions have improvement in efficiency, on the average, while Giresun region has a decline in efficiency. All regions have technical regress over the period 20042008. For this, except for Ordu region, the other regions have experienced decrease total factor productivity growth due to regress in technical change. However, some individual cooperatives namely, Akçakoca, Alaplı, Bartın, Çilimli, Çamlaş, Gölköy, Kumru, Ordu, Ünye, Eynesil, Arakl1, Derecik, and Maçka experienced growth in total factor productivity during this period. 
As a conclusion, we have tried to explore in this study the relative performance and the sources of the performance of the HASCUs. Our empirical findings may have important implications for policy targeting. Also the reason of inefficiencies of some cooperatives should be discovered and take action to improve them. Because of the hazelnut production has a strategic importance in Turkish agriculture. Turkey is a leader country in terms of production. However, world prices of hazelnut are determined by Hamburg Stock Exchange. Therefore, hazelnut stock exchange can be constituted in Turkey and world prices should be determined by Turkey.

\section{REFERENCES}

1. www.fiskobirlik.gov.tr

2. www.ieuhazelnut.org/hazelnut-production.aps

3. www.gursoy.com.tr/content/view/287/247/lang/en

4. T.J. Coelli and D.S.P Rao, Implicit Value Shares in Malmquist TFP Index Numbers, Centre for Efficiency and Productivity Analysis, CEPA Working Papers, 4, Department of Econometrics, University of New England, Australia Working Papers, 1-27,2003.

5. A.Ö. Önder, E.Deliktaş ve M.Karadağ, The comparison of DEA and SFA Methods in the efficiency of the Turkish Manufacturing Industry, DEÜ, IIIBF Journey,18-1,71-92. İzmir,2003.

6. C.A.K, Lowell, Production Frontiers and Productive Efficiency in Fried, H.O., C.A.K., Lovell ve S.S. Schmidt (Eds.), The Measurement of Productive Efficiency, Oxford University Press, 3-67, New York,1993.

7. R. Fare, Grosskopf, S., M. Norriss, Z.Y.Zhang, Productivity Growth, Technical Progress and Efficiency Change in Industrialized Countries, The American Economic Review, March, Vol.84,66-80,1994.

8. A.I. Ali and L.M. Seiford, The Mathemetical Programming Approach to Efficiency Analysis in Fried H.O., C.A.K. Lovell and S.S. Schmidt (Eds), The Measurement of Productivity Efficiency, Oxford University Press,, 120-159, New York,1993.

9. A. Charnes, W. Cooper, A.Y. Lewin, L.M, Seiford, Data Envelopment Analysis : Theory, Metodology and Applications, Kluwer Academic Publishers, Boston, 1995.

10. Seiford, L.M., (1996). "Data Envelopment Analysis, The Evolution of the State of the Art (1978-1995)", Journal of Productivity Analysis 7(2/3), 97-137.

11. T.J. Coelli, D.S.P. Rao, G.E. Battase, An Introduction to Efficiency ve Productivity Analysis, Kluwer Academic Publishers, Boston,1998.

12. O. Zaim ve F. Taşkın, The Comparative Performance of Public Enterprise Sector in Turkey: A Malmquist Productivity Index Approach, Journal of Comparative Economics 25, 129-157,1997.

13. M. Karadağ and E. Deliktaş, Growth of Factor Productivity in the Turkish Manufacturing Industry at Provincal Level, Regional Studies, Vol 39.2, pp.213-223, 2005.

14. E.H. Çakmak and O. Zaim, Türkiye'de Tarım Kesiminde Etkinlik, ODTÜ Gelişme Journey, 19(3), ss.305-316, Ankara,1992.

15. A. Arnade Carlos, Using Data Envelopment Analysis To Measure International Agricultural Efficiency and Productivity, United States Department of Agriculture, Technical Bulletin Number 1831, 1-26,1994. 

Agricultural Sales Cooperatives Unions in Turkey

16. K.Suhariyanto and C.Thirtle, Asian Agriculture Productivity and Convergence, Journal of Agricultural economics, Vol, 52(3), 96-110,2001.

17. G.B. Nkamleu, Productivity Growth, Technical Progress and Efficiency Change in African Agriculture, African Development Review, Vol, 16(1), 2003-222,2004.

18. M. Candemir and E.Deliktaş, Küçük Menderes Havzası Gıda İşletmelerinde Üretim Etkinliği ve Etkinliği Etkileyen Olası Faktörler, Verimlilik Journey, MPM Publication, No 2. ss.89-96. Ankara,2005.

19. E. Deliktaş, Ş. Ersungur, M.Candemir, The Comparison of Agricultural Efficiency and Productivity Growth in the EU and TURKEY, 1980-2002, Yaşar University International Conference on Business Management and Economics, 15-18 June, Çeşme, İzmir,2005.

20. M. Candemir and N. Koyubenbe, Efficiency of Dairy Farms in the Province of Izmir- Turkey. Data Envelopment Analysis (DEA), Journal of Applied Animal Research, ISSN, 29(42) 4,India,2006.

21. M. Candemir and E. Deliktaş, The Analysis of Production Efficiency and Total Factor Productivity State Agricultural Enterprises in Turkey, Journal of Agriculture Economics Review. Vol 8, No 2, ISSN 1109-2580, Aristotele University of Thessaloniki School of Agricultural Science, Department of Agricultural Economics, Thessaloniki- GREECE,2007.

22. A. Charnes, W. Cooper, E. Rhodes, Measuring the Efficiency of Decision Making Units, European Journal of Operational Research, Vol.2, 429-444,1978.

23. T.J. Coelli, A Guide to DEAP Version 2.1: A Data Envelopment Analysis Program, CEPA Working Papers, 8/96,Department of Econometrics, University of New England, Australia,1-49,1996.

24. V.W. Ruttan, Productivity Growth in World Agriculture: Sources and Constraints, Journal of Economic Perspectives, 16, 161-184, 2003. 